\title{
Ann Arbor Stage III Extranodal Marginal Zone Lymphoma of Mucosa-Associated Lymphoid Tissue
}

National Cancer Institute

\section{Source}

National Cancer Institute. Ann Arbor Stage III Extranodal Marginal Zone Lymphoma of Mucosa-Associated Lymphoid Tissue. NCI Thesaurus. Code C5087.

Extranodal marginal zone lymphoma of mucosa-associated lymphoid tissue presenting as stage III disease. 